\title{
The Influence of Perceived Organisational Justice on Customer's Trust: An Overview of Public Higher Educational Students
}

\author{
Nor Sabrena Norizan ${ }^{1}$, Ahmad Fadhly Arham ${ }^{2}$, Mohd Natashah Norizan ${ }^{34}$ \\ ${ }^{1,2}$ Faculty of Business and Management, Universiti Teknologi Mara (UiTM), Melaka, \\ Malaysia, \\ ${ }^{3}$ School of Microelectronic Engineering, Universiti Malaysia Perlis (UNIMAP), Perlis, \\ Malaysia \\ ${ }^{4}$ Centre of Excellence Geopolymer and Green Technology (CeGeoGTech), Universiti \\ Malaysia Perlis,(UNIMAP), Perlis, Malaysia
}

\begin{abstract}
This paper focused on the issues of customer's trust within the telecommunication industry in Malaysia. This paper looked into the importance of perceived organisational justices towards customer trust. In the event of service recovery, it is important for the managers to monitor closely the current processes (procedural justice), outcomes (distributive justice) and the communication between employee and customer (interactional justice). This with help the organisation to maintain customer loyalty and minimize customer switching to a different mobile provider. Primary data is collected through survey questionnaires from 181 customers who are the major mobile users in the industry. Likert scales were used and all variables demonstrated good values of consistency. This study found that, procedural justice, distributive justice and interactional justice are all having significant relationship towards customer trust. It is an indication that perceived organisational justice is an important antecedent for customer trust especially during service recovery period.
\end{abstract}

Keywords: Service Failure, Service Recovery, Perceived Organisational Justice, Customer Trust, $\underline{\text { Telecommunication industry }}$

\section{INTRODUCTION}

In today's modern economy, rapid competitive advantage and technological advancement have made the organisation to become aware of the importance of having a good relationship with customers and the need to increase the customer retention rate [1]. Customer retention is an activity that helps the organisation to reduce the number of service failure as a decrease in customer's retention rate will lead to the loss of profit, switching service provider and the loss of trust [2]. Handling dissatisfied and customer churn are few of the serious problems for the mobile service provider and it becomes worse every each day as the annual churn rate ranges from 20 percent to 40 percent for most of the companies within global telecommunication industry $[3,4,56]$. The customers churn gave a big impact on the telecommunication industry in term of great deal of price premium, decreasing in company profit, loss of potential customers as well as loss of customer's trust [7].

Telecommunication industry in Malaysia was found to be one of the critical areas in customer retention as to date, it has experienced major development progress [8]. The telecommunication industry operations are complicated and vary across markets within a customer market. In October 2008, Malaysia has launched the Mobile Number Portability (MNP) making the Malaysian mobile telecommunication industry one step forward [9]. The introduction of MNP has increased the rapid competition amongst the telecommunication industry as the customers are allowed to change mobile provider at any time while maintaining their current mobile number which giving a challenge to the mobile service provider in retaining their customers. 


\section{PROBLEM STATEMENT}

Service failure is the issues that most organisations experienced and it is something that completely avoided $[10,11]$. No business organisations could provide a perfect service system, even the greatest businesses sometimes suffered from service delivery problems [12]. The organisation needs to find ways on how to gain back the trust that they have lost due to the service failure as trust is difficult to build. The importance of trust cannot be overlooked because trust is the critical element in assuring customer satisfaction, loyalty and purchase intention $[13,14$, $15,16,17]$. The organisation needs to be careful in handling service failure because customers can easily lose their trust and spread negative word of mouth through varied communication channels [18, 19]. It is found that 86 percent of the service failure event is the most customer's unforgettable moment. [20].

For the purpose of this study, this paper focused on the issues of customer's trust due to trust is an important element in establishing and maintaining long-term relationship between organisations and customers [21]. When the customers lose their trust with the organisation, they can switch to the other options available in the industry. As in Malaysia itself, there were six major mobile service providers competing in the industry. All these mobile service providers are regulated by the Malaysian Communication Multimedia Commission (MCMC). In 2018, MCMC discovered that there were 49,065 complaints from the customers regarding the quality of telecommunication in Malaysia [22]. Poor services in Malaysian telecommunication industry has led to 35 percent of customer complaints, content with 16.7 percent, bill and charging with 13.9 percent, poor service coverage with $(3.5 \%)$. It is found that, throughout June to December 2018, 90 percent of service providers failed to comply with the regulation to resolve the customer's complaint.

Hence, a well-implemented service recovery strategy is important to gain customer confidence and trust back after the service failure. Service recovery is essential for the organisation [23] but few companies implemented effective service recovery strategies to bring back dissatisfied customer to satisfied conditions [24]. Therefore, this paper aims to examine the influence of perceived organisational justice on customer's trust in the telecommunication industry.

\section{LITERATURE REVIEWS PERCEIVED ORGANISATIONAL JUSTICE (POJ)}

In order to determine the customers' response after the service failure, this paper decided to use justice theory as the main framework in identifying the service recovery procedures. Perceived organisational justice is a significant variable in the service recovery research that linked to the customer's satisfaction with the comprehension of service failure [8]. Tax and Brown proven that POJ is the main model applied during the service recovery strategies and helped to identify the customer service fairness during the service recovery [25]. The antecedents of POJ was described in most research as unidimensional or multidimensional and in Malaysia and it is found that past researchers on justice are restricted to human resources areas.

Thus, this paper will verify the importance of POJ in the customer service areas as there is a lack of study being conducted within this area. It is discovered that perceived organisational justice is relevant in defining the fairness of the customers' perceived recovery effort. In order for the organisations to make an effective effort to service recovery, it is essential if the organisation can first identify the dimension of justice which consist of three elements that are procedural, distributive and interactional justice [26, 27]. Basically, the three dimensions of justice indicated are linked to organisational policies and processes (procedural), financial reward (distributional) and staff relationship and client's reaction during the service failure (interactional) $[24,28]$.

\section{Procedural Justice (PJ)}

There are several definitions from past literatures in defining procedural justice. For instance, Choi and Choi defined procedural justice as the customer's perceived fairness in the processes and procedures used by the organisation in dealing with the problems arising during the service failure [29]. The processes and procedures being used can be in the aspect of accessibility, timing/speed/process 
control, delay and flexibility. Moreover, PJ also can be defined as customer's perception on the equity of the policies and procedures used by the organisaiton in service recovery that helps to increase customer satisfaction [26, 30]. Thibaut and Walker in 1975 have introduced the six antecedents of procedural justice to make sure that customers perceived the procedures being used within the organisation to be unbiased, reliable, correct and ethical [31]. The six elements deemed to be fair when it is acceptable by customer over time, not biased, precise, containing strategies for overcoming wrong decisions, adhering to prevailing morality concepts and considering the suggestions produced by the affected groups and implying with the process and decision control.

It is found that there is a significantly relationship between PJ and customer's trust [32, 33]. It is because the customer uses $\mathrm{PJ}$ views as an alternative in determining whether they can trust the organisation and recognise its authority because procedural fairness beliefs act as an exploration or mental shortcut for more complex trust judgment that the process calls the procedural fairness heuristic [34]. Thus, the following hypothesis is proposed:

$\mathrm{H}^{1}$ : There is a relationship between procedural justice and customer's trust

\section{Distributive Justice (DJ)}

Distributive justice (DJ) is referred to the customer's perceived fairness with the distribution of outcomes made by the organisation [35, 36]. The DJ is considered to be fair when it is complying with the chosen norms of allocation. Choi and Choi indicated that DJ is the customer's perceived fairness of the outcomes used by the organisation during the recovery effort [29]. It can be in the forms of discounts, refund and store credits.

DJ is essential in maintaining a good connection between the organisation and customers as it includes the distribution of expenses and benefits and DJ enables the organisation to correct and reimburse during the service failure [16,37]. Chebat and Slusarczyk proven that DJ has significantly impact on the customer's trust, emotion and customer satisfaction outcomes [38]. It is because the customer will always anticipate that the organisation is fair in the distribution of the outcomes and treat them well or otherwise, they will be dissatisfied and loss of confidence with the organisation [28]. Thus, the following hypothesis is proposed:

$\mathrm{H}^{2}$ : There is a relationship between interactional justice and customer's trust

\section{Interactional Justice (IJ)}

Interactional justice (IJ) can be referred to the method and treatment provided by the organisation in handling service failure [39]. It comprises of the components of courtesy, politeness and effort used by the organisation during the phase of service recovery. Previous researchers have confirmed that $\mathrm{IJ}$ is also related to the customer's view on equity to the personal treatment received from the organisation in regard sincerity, education and dignity when confronted with service failure [30, 11].

IJ is discovered to be highly related to customer's trust because if the company shows a lack of interest during service recovery effort, the customers will suffer with adverse feeling and loss of trust [27]. Therefore, the greater the amount of concern provided by service provider, the more levels of customer of satisfaction will be [27]. Thus, the following hypothesis is proposed:

$\mathrm{H}^{3}$ : There is a relationship between distributive justice and customer's trust

\section{Customer Trust}

Trust can be referred to the confidence of one party has in someone and when parties view potentially high-risk actions as being prudent because of the belief that their partner will not act opportunistically $[40,41]$. Trust is important in-service organisation in retaining the relationship between customers and organisation because customers frequently want to make a purchase decision before they experience the service [28]. Normally, the strength and quality of a relationship relies on the level of trust, as in, the higher the level of trust, the stronger the relationship will be [42]. Customers will only learn to trust companies if the customers contact the employees and engage in deep acting before the encounter starts 
and consequently feel what they are required to feel during the encounter [43].

It is expected that service failure has influence on post-recovery trust, commitment and negative word of mouth and most of the researchers have found that once the customer perceived negatively about the service failure in the organisation, it will have an impact on the customer's future relationship with a service organisation [44, 45]. Previous research has confirmed that trust is one of the interpreters to the service recovery [25]. Finally, many studies also have confirmed that when the customer receives a fair treatment it will help to gain the customer's trust towards the organisation [42].

\section{METHODOLOGY}

This study is a quantitative research that intends to determine the relationship between perceived organisational justice and customer's trust. The population for this study was students in one of the public higher education universities in Selangor, Malaysia. The individual students were chosen as the unit of analysis they are among the major users and subscribers of Malaysia mobile phone services [46]. This study only finalized data from customers who have experienced service failure that is associated with the products and services offered by the organisation. The cross-sectional design was used and the total numbers of 327 questionnaires had been distributed. It is discovered that, out of 327 respondents there were 181 respondents who have made complaint during the service failure. Thus, the number of samples of this study is only 181 .

Questionnaires were distributed to the students of different programs in proportion to the number of students in their respective programs. Questionnaires were also distributed in respect to the types of Malaysia mobile phone services. Convenience sampling was used as a sampling technique for this study. The instrument for this study was a survey questionnaire. The questionnaires were adapted from the previous researchers and five-point likert scale (1-Strongly Disagree, 2-Disagree, 3-Neutral, 4-Agree and 5Strongly Agree) were used to measure the customer's response. The questionnaires were distributed by hand to each of the selected respondents involved in this study. The result for
Cronbach Alpha were ranging between 0.6 to 0.8, therefore it is deemed to be reliable for further analysis.

\section{ANALYSIS AND DISCUSSION}

The data collected in the study was analysed by using the Statistical Package for Social Sciences (SPSS) version 22.0. The relationship between dimensions of justice and customer satisfaction among complainant was investigated by using the Pearson Product Moment Correlation Coefficient.

Table 1: Pearson Correlation Coefficient Result

\begin{tabular}{|c|c|c|c|c|}
\hline & & PJ & DJ & IJ \\
\hline \multirow{4}{*}{$\begin{array}{c}\text { Customer } \\
\text { Trust }\end{array}$} & $\mathbf{r}$ & 0.258 & 0.413 & 0.494 \\
\cline { 2 - 5 } & p-value & 0.000 & 0.000 & 0.001 \\
\cline { 2 - 5 } & Strength & Weak & Moderate & Moderate \\
\cline { 2 - 5 } & & $\begin{array}{c}\mathrm{H}^{1} \\
\text { Supported }\end{array}$ & $\begin{array}{c}\mathrm{H}^{2} \\
\text { Supported }\end{array}$ & $\begin{array}{c}\mathrm{H}^{3} \\
\text { Supported }\end{array}$ \\
\hline
\end{tabular}

The result from the analysis shows that there is a significant relationship between procedural justice and trust $(\mathrm{r}=0.258 ; \mathrm{p}<0.001)$. Thus, $\mathrm{H} 1$ is supported. The result is in line with those of Kau and Loh whereby procedural justice has a positive relationship with trust but in the lower impact [47]. Different to Ruyter and Wetzels who in their research stated that procedural justice has an influence on customer's trust during the service recovery effort which at the same time it helps to improve scores for service quality, customer satisfaction, customer loyalty and trust [48]. Previous researchers also stated that procedural justice is a determinant that influences customer satisfaction and trust with the services and products by the organisation to the customer $[32,33]$. In addition, Lind suggested that people use procedural justice in examining whether or not they can trust the organisation and accept its authority [34]. The result was also supported by Casado, Ruiz and Kasper who in their research had stated that, during the service recovery effort, the organisation can help to retrieve back the customer trustworthiness towards their organisation [49]

The result from the analysis above also shows that there is a significant positive relationship between distributional justice and customer's trust $(\mathrm{r}=0.413$, 
$\mathrm{p}<0.001)$. The result is supported by Kau and Loh who stated that distributional justice is highly related to customer's trust as compared with the other two justice theories [47]. It is found that the customers really care about the outcomes that they received from the organisation after the service failure. If they found the outcomes to be fair, they will still use the company's products and services. Besides, Clammer also confirmed that distributional justice has the largest impact on the customer satisfaction which is trust [50] Previous researchers, Weun, Beatty and Jones also confirmed that in the overall customer satisfaction level, distributional justice has significantly impact the service quality, customer satisfaction, loyalty and trust [51]. The researchers also stated that, distributional justice is very important to the customer even to the lower extent. In addition, Robbins and Miller also confirmed that during service recovery, distributional justice has significantly affects the customer's reaction [52].

Finally, the result from the analysis also shows that there is a significant relationship between interactional justice and trust $(\mathrm{r}=0.494, \mathrm{p}<0.01)$. This finding finds support to Weun et al., that interactional justice which consists of the apology determinant can only enhance the score for trust [51]. This is because when the organisation apologizes to the customer's during the service recovery, it does not inflate the perception of fairness. It is also supported by Kau and Loh whom stated that interactional justice has a positive relationship toward level of customer satisfaction [47]. It is because the employee has to overcome the customer's trust after the service failure and it makes the customer trust the organisations' products and services.

\section{CONCLUSIONS}

As a conclusion, it can be concluded that there was a significant relationship between perceived organisational justice and customer's trust. It is expected that the organisation can use perceived organisational justice as a way during the recovery effort. The result from this study showed that POJ is an important element to retain customer when service failure had happened. It is because by implementing a good service recovery effort that consist of procedural, distributive and interactional justice can make the customer believes that the organisation will provide a fair process and procedures, decision making, accessibility and on time delivery even after the service failure. Moreover, the customers believe that the organisation will provide a fair treatment (politeness and empathy) and good explanation during the interaction with the customer on how to overcome the service failure issues. Furthermore, customers will spread positive word of mouth if they are satisfied with the outcomes they received during the recovery effort and therefore, make them wants to build a long-term relationship and increase their trustworthiness towards the organisation.

It is important for all mobile service providers to consider the essentials of perceived justice in delivering services or products to their customers and it should not be overlooked. The managers need to monitor closely the current processes (procedural justice), outcomes (distributive justice) and the communication between employee and customer (interactional justice). This is important because the result obtained indicated that perceived customer dimension of justice may influence the customer's trust. Due to that it is hoped that this study can benefit all companies that experiencing service failure and find ways on how to make the customer happy with the products and services being offered by the organisation.

Finally, this study is not without limitations. First, this study only provide a snapshot of a single moment in time. Thus, a longitudinal data might overcome this issue in the future. Second, to ensure the generalizability of the findings, future research is recommended to carry out probability sampling procedures.

\section{REFERENCES}

[1] Nasir, A. \& Mustaq, H. (2014). Customer Loyalty in Telecom Sector of Pakistan. Journal of Sociological Research, 5 (1), 449467.

[2] Kiant, G. J. (2013). Customer Retention: Investigating the Dimensions in the Telecommunication Industry (Universiti Malaysia Sarawak), (Master Thesis). (UMI No. 1000246902).

[3] Berson, A., Smith, S. \& Therling, K. (1999). Building Data Mining Applications for CRM. New York: McGraw-Hill. 
[4] Madden, G., Savage, S. J. \& Coble-Neal, G. (1999). Subscriber Churn in the Australian ISP Market. Information Economics and Policy, 11 (2), 195-207.

[5] Parks Associates. (2003). US Mobile Market Intelligence, August 2019.

[6] Kim, M., Park, M. \& Jeong D. (2004). The Effects of Customer Satisfaction and Switching Barrier on Customer Loyalty in Korean Mobile Telecommunication Services. Telecommunications Policy, 28 (2), 145-159.

[7] Reicheld, F. E., Sasser, W. E. (1990). Zero defections: quality comes to services. Harvard Business Review, 68, 105-11.

[8] Piaralal, S. K., Piaralal, N. K. \& Bhatti, M. A. (2015). A Structural Equation Modeling of Perceived Justice in Malaysian Telecommunication Sector, Asian Social Science, 11 (4), 77-89.

[9] Malaysian Communications and Multimedia Commission. (2009). HSBB Malaysia's Drive for High Speed Broadband, My Converge. Retrieved from https://www.skmm.gov.my/skmmgovmy/med ia/General/pdf/MYC04_all_lowres.pdf

[10] Bailey, D. (1994). Recovery from Customer Service Shortfalls. Managing Service Quality, 4 (6): 25-28.

[11] Smith, A. K. \& Bolton, R. N. (1998). An Experimental Investigation of Customer Reactions to Service Failure and Recovery Encounters: Paradox of Peril? Journal of Services Research, 1 (1), 65-81.

[12] Nikbin D., Ismail, I., \& Abu Jarad, I. Y. (2011). The Impact of Firm Reputation on Customer's Responses to Service Failure: The Role of Failure Attributions. Business Strategy Series, 12 (1), 19-29.

[13] Ribbink, D., Van Riel, A., Liljander, V., \& Streukens, S. (2004). Comfort Your Online Customer: Quality, Trust, and Loyalty on the Internet. Managing Service Quality, 14 (6).

[14] Gefen, D., Karahanna, E. \& Straub, D. W. (2003). Trust and TAM in online shopping: An integrated model. MIS Quarterly, 27 (1).

[15] Kim, C., Zhao, W. \& Yang, K. H. (2008). An Empirical Study on the Integrated Framework of E-Commerce in Online Shopping: Evaluating The Relationships Among Perceived Value, Satisfaction, and Trust Based on Customers?. Journal of Electronic Commerce in Organisations, 6 (3), 1-19.

[16] Kim, J., Jin, B. \& Swinney, J. L. (2009). The Role of Retail Quality, E-Satisfaction And Etrust In Online Loyalty Development Process. Journal of Retailing and Consumer Services, 16 (4), 239-47.

[17] Chiu, C. M., Chang, C. C. , Cheng, H. L. \& Fang, Y. H. (2009). Determinants of Customer Repurchase Intention in Online Shopping. Online Information Review, 33 (4), 761-784.

[18] Crie, D. (2003). Consumers' Complaint Behaviour. Taxonomy, Typology and Determinants: Towards a Unified Ontology. Journal of Database Marketing and Customer Strategy Management, 11, 60-82.

[19] Maxham, J. G. (2001). Service Recovery's Influence on Consumer Satisfaction Positive Word of Mouth and Purchase Intentions. Journal of Business Research, 54 (1), 11-24.

[20] Morgan, R. M. \& Hunt, S. D. (1994). The Commitment-Trust Theory of Relationship

Marketing. Journal of Marketing, 58 (3), 20.

[21] Rousseau, D. M., Sitkin, S. B., Burt, R. S. and Camerer, C. (1998). Not So Different After All: A Cross-Discipline View of Trust. Academy of Management Review, 23, 393-404.

[22] Malaysian Communications and Multimedia Commission. (2019). MCMC: Telcos in Malaysia Don't Resolve Complaints in Time. Retrieved from https://www.google.com/search?q=MCMC\% $3 \mathrm{~A}+$ Telcos+in+Malaysia+don\%E2\%80\%99t+ resolve+Complaints+in+time \&oq $=\mathrm{MCMC} \% 3$ $\mathrm{A}+\mathrm{Telcos}+\mathrm{in}+$ Malaysia+don\%E2\%80\%99t+r esolve+Complaints+in+time \&aqs $=$ chrome.. 69 i57j69i58.542j0j7\&sourceid $=$ chrome $\&$ ie $=U T$ F-8

[23] Zeithaml, V. A., Berry, L. L. \& Parasuraman, A. (1996). The Behavioral Consequences of Service Quality. Journal of Marketing, 60 (2), 31-46.

[24] Bitner, M. J., Booms, B. H., \& Tetreault, M. S. (1990). The Service Encounter, Diagnosing Favorable and Unfavorable Incidents. Journal of Marketing, 54, 71-84.

[25] Tax, S. S. \& Brown, S. W. (1998). Recovering and Learning from Service Failure. Sloan Management Review, 40, 75-88. 
[26] Blodgett, J. G., Hill, D. J., \& Tax, S. S. (1997). The Effects of Distributive, Procedural, and Interactional Justice on Post-Complaint Behavior. Journal of Retailing, 73, 185-210.

[27] Sparks, B. A. \& McColl-Kennedy, J. (2001). Justice Strategy Options for Increased Customer Satisfaction in A Services Recovery Setting. Journal of Business Research, 54 (3), 209-218.

[28] Spreng, R. A \& MacKoy, R. D. (1996). An Empirical Examination of a Model of Perceived Service Quality and Satisfaction. Journal of Retailing, 72 (4), 201-214.

[29] Choi, B., \& Choi, B. J. (2014). The Effects of Perceived Service Recovery Justice on Customer Affection, Loyalty, and Word-Of Mouth. European Journal of Marketing, 48(1/2), 108-131.

[30] Maxham, J. G. \& Netemeyer, R. G. (2002). A Longitudinal Study of Complaining Customer's Evaluations of Multiple Service Failures and Recovery Efforts. Journal of Marketing, 66 (4), 57-71.

[31] Thibaut, J. W. \& Walker, L. (1975). Procedural Justice: A Psychological Analysis, Lawrence Erlbaum and Associates. Hillsdale: NJ.

[32] Teo, S. H \& Lim, V. K. G. (2001). The Effects of Perceived Justice on Satisfaction and Behavioral Intentions: The Case of Computer Purchase. International Journal of Retail \& Distribution, 29 (2), 109-125.

[33] Sindhav, B., Holland, J., Rodie, A. R., Adidam, P. T. \& Pol, L. G. (2006). The Impact of Perceived Fairness on Satisfaction: Are Airport Security Measures Fair? Does It Matter?'. Marketing Theory and Practice, 14 (4), 323336.

[34] Lind, E. A. (2001). Fairness Heuristic Theory: Justice Judgments as a Pivotal Cognition in Organisational Relations in Greenberg, $\mathbf{J}$ and Cropanzano, R. (Eds), Advances in Organisational Justice Stanford.

[35] Adams, J. S. (1965). Inequity in social exchange. in L. Berkowitz (Ed.), Advances in Experimental Social Psychology. Academic Press, New York: NY, 267-269.

[36] Leventhal, G. S. (1976). The Distribution of Rewards and Resources in Groups and Organisations. in L. Berkowitz, \& E. Walster (Eds.), Equity Theory (pp. 92-131). Toward a
General Theory of Social Interaction, Academic Press, New York, NY.

[37] Del Río-Lanza, A. B., VázquezCasielles, R., \& Díaz-Martín, A. M. (2009). Satisfaction with Service Recovery: Perceived Justice and Emotional Responses. Journal of Business Research, 62 (8), 775-781.

[38] Chebat, J. C. \& Slusarczyk, W. (2005). How Emotions Mediate the Effects of Perceived Justice on Loyalty in Service Recovery Situations: An Empirical Study. Journal of Business Research, 58 (5), 664-673.

[39] Karatepe, O. M. (2006). Customer Complaints and Organisational Responses: The Effects of Complainants' Perceptions of Justice on Satisfaction and Loyalty. International Journal of Hospitality Management, 25(1), 69-90.

[40] Moorman, C., Deshpande, R., \& Zaltman, G. (1993). Factors Affecting Trust in Market Research Relationships. Journal of Marketing, 57, 81-101.

[41] Morgan, R. S. \& Hunt, S. (1994). The Commitment-Trust Theory of Relationship Marketing. Journal of Marketing, 58 (3), 2038.

[42] Yau, O. H. M., Lee, J. S. Y., Chow, R. P. M., Sin, L. Y. M. \& Tse, A. C. B. (2000). Relationship Marketing the Chinese Way. Business Horizons. 43 (1), 16-24.

[43] Gruber, T. (2011). I Want to Believe They Really Care: How Complaining Customers Want To Be Treated By Frontline Employees. Journal of Service Management, 22 (1), 85110.

[44] Bell, C. R \& Zemke, R. E. (1987). Service Breakdown: The Road to Recovery. Management Review, 32-35.

[45] Berry, L. L. \& Parasuraman, A. (1991). Marketing Services: Competing Through Quality, Free Press, New York, NY.

[46] Hakoama, M. and Hakoyama, S. (2011) The Impact of Cell Phone Use on Social Networking and Development among College Students. The AABSS Journal, 15, 1-20.

[47] Kau, A. \& Loh, E. W. (2006). The Effects of Service Recovery on Consumer Satisfaction: A Comparison Between Complainants and NonComplainants. Journal of Services Marketing, 20 (2), 101-111.

[48] Ruyter, K. D. \& Wetzels, M. (2000). Customer Equity Considerations in Service Recovery: A Cross-Industry Perspective. International 
Norizan, N. S, Arham, A. F. \& Norizan, M. N./International Journal of Business and Management, 3(2) 2019, Pages: 01-08

Journal of Service Industry Management, 11 (1), 91-108.

[49] Casado-Díaz, A. B., Mas-Ruiz, F. J. \& Kasper, H. (2007). Explaining Satisfaction in Double Deviation Scenarios: The Effects of Anger and Distributive Justice. International Journal of Bank Marketing, 25 (5), 292-314.

[50] Clemmer, E. C. (1993), in Cropanzano, R. (Eds). Justice in the Workplace: Approaching Fairness in Human Resource Management, Lawrence Erlbaum Associates, Hillsdale, NJ.

[51] Weun, S., Beatty, S. E., \& Jones, M. A. (2004). The Impact of Service Failure Severity On Service Recovery Evolutions and PostRecovery Relationships. Journal of Services Marketing, 18 (2), 133-146.

[52] Robbins, T. L. \& Miller, J. L. (2004). Considering Customer Loyalty In Developing Service Recovery Strategies. Journal of Business Strategies, 21 (2), 95-109. 